Anna Kowalcze-PaWliK

University of Lodz

iD https://orcid.org/0000-0002-7606-7127

\title{
On "Savage and Deformed Slave": Bodily Difference in Selected Contemporary Productions of The Tempest in Poland
}

\begin{abstract}
Dis/ability is a dynamic category produced in a complex constellation of factors that includes not only stigmatised mental and physical constraints or physiological differences, but also a manifestation of incapacity that is recognised or produced by law, social norms and the very way of thinking about the nature of bodily vulnerability. The meanings of dis/ability are thus culturally and historically dependent. Therefore, the manner in which dis/ability is presented on a theatrical stage can be considered not only as an important factor influencing the interpretation of a given production but also as a test for the dominant thinking of disability at a given point of time, in a given culture. The departure point for this paper is a brief discussion of the visibility of medieval models of dis/ability in Shakespeare's plays and a reflection on how the reception of these dramatic texts has changed over time depending on the paradigmatic shifts in thinking about dis/ability, especially with the emergence of disability studies and the growing theoretical reflection on the position of dis/ability in theatre. An especially interesting case in point is the reception of Caliban as a character whose stigmatisation can be expressed through bodily difference. Thus, the paper focuses on what seems to be a systematic aberrant decoding of The Tempest in three twenty-first century Polish productions of the play.
\end{abstract}

Keywords: Caliban, Polish theatre, disability studies, The Tempest, Shakespeare in performance

Dis/ability in theatre is a complex topic that can be approached from many angles that might or might not include the ethical and therapeutic aspects of art therapy, participation of actors with dis/abilities in theatre, as well as the representation of dis/ability on the page and on the stage. At the same time, dis/ability in itself is a category whose application to texts produced in the past constitutes a certain interference in the patterns of reading and spectating. Paul Longmore writes in Why I Burned My Book and Other Essays on Disability that dis/ability 
is produced in a dynamic game of a complex constellation of factors that includes not only stigmatised mental and physical constraints or physiological differences. The definition proposed by the Oxford English Dictionary (OED) defines disability as a manifestation of incapacity, a physical or mental state that limits a person's actions or sensory perception, especially their ability to work (OED online). This in/ability is recognised or produced by law, social norms and patterns of thinking about what the body is, what health is, and what bodily vulnerability might be; to a large extent, then, dis/ability is an issue of perception and reception of the body considered as non-standard or non-normative. Dis/ability in theatre seems then to work as a multiple construct: what it means depends on how characters with disabilities are presented on the page, on the stage, and also how they are received by the spectators, revealing a dynamic and mutable constellation of meanings instead of one stable category.

In the performance history of The Tempest, a lot of attention has been given to Caliban, whose role in the play was downplayed before the nineteenth century but who becomes a figure of central importance in de-centring, postmodern, postcolonial readings. These tend to accentuate the ontological, political, and social disadvantage "Monsieur Monster" is pushed into by Prospero, Miranda and the castaways. This disadvantage has been addressed in modern productions in a variety of ways, which fashioned Caliban into a wild man, a human-fish hybrid, a black slave, and recently also a person with disabilities. ${ }^{1}$ Even though, arguably, one would not note a "critical avoidance" (Bolt, 2012: 287) in the discussion of disability in Shakespeare's plays, The Tempest does not present itself as a text falling within the immediate perimeters of disability studies analysis. However, as the recent papers presented at the SAA 2021 Shakespeare's Other Disability Plays seminar suggest, interpreting The Tempest through such a lens is possible and productive. ${ }^{2}$ Jeffrey Wilson, who discusses stigmatisation of Caliban in the play, notes accordingly:

The ambiguous and therefore amorphous nature of Caliban's deformity has been a perennial problem in both dramaturgical and critical studies of The Tempest at least since George Stevens's edition of the play (1793), acutely since Alden Vaughan and Virginia Mason-Vaughan's Shakespeare's Caliban:

${ }^{1}$ For Caliban's reception history, see Wilson (1873); McCloskey (1940); Hankins (1947); Sharp (1981); Griffiths (1983); Nixon (1987); Hall (1995); Franssen (1997); Burnett (2007); Rundle (2007); Jaczminski (2009); Kowalcze-Pawlik (2011); Wilson (2018); and above all, Vaughan and Vaughan (1993).

${ }^{2}$ Shakespeare's Other Disability Plays, Shakespeare Association of America 2021, Seminar 44, organised by Bellee Jones-Pierce and Lindsey Row-Heyveld. Caliban's disability was discussed by Leslie Dunn, "Disabling Caliban" and Anna Kowalcze-Pawlik, "Not Honour'd with a Human Shape:' Malignant Things, Skin-Deep (T)error and the Promise of the Monstrous in The Tempest." 
A Cultural History (1993), and enduringly in recent readings by Paul Franssen, Julia Lupton, and Mark Burnett. (Wilson, 2018: 146)

This essay discusses the production of bodily difference in Polish productions of The Tempest that focus on Caliban as the character whose imperfect subjectivity is emphasised throughout the play and whose bodily difference, for a long time read as monstrosity, has lent itself to manifold interpretations, re-visions and critical re-tellings. The interest in dis/ability in Shakespearean drama is a relatively new trend, reaching back to such pre-disability studies publications as Herbert Covey's "Shakespeare on Old Age and Disability" (Covey, 2000), a seminar on bodily and metaphorical deformities at the Shakespeare Association of America conference (2009), and the special issue of Disability Studies Quarterly (2009) entitled Disabled Shakespeares. As Covey already points out in his sketch discussing the theme of disability and old age in Shakespeare's drama, characters with disabilities are constructed around their dis/ability "to add dimension to characters and set them apart" (Covey, 2000: 169) - something that within the disability studies paradigm has been called a "narrative prosthesis" (Mitchell and Snyder, 2000). In his rather sketchy essay, Covey establishes a mistaken link between Trinculo's description of Caliban in Act 2, scene 2 and "raree shows" instead of a fair with elements of what should be more properly called an early modern equivalent of a freak show; ${ }^{3}$ he is correct, nonetheless, in recognising a connection between the gaze of the spectator, "the entertainment value of characters with disabilities or deformities," and the exploitation of staged disability (Covey, 2000: 181).

These issues were engaged and critically explored in Disabled Shakespeares. Already in this collection, a wide thematic spectrum of research on disability in the works of the Stratford playwright was apparent. The articles emphasised the importance of the discourse of disease and deformation both for the metaphorical language of the drama and for the very construction of the characters, often focusing on a bodily change or disability leading to a stigmatised, defective subjectivity, whose beginning is a wound, blindness, lameness, epilepsy, intellectual disability, or a nervous breakdown. This research focused, however, on the non-normative bodies of Caesar, Katherine, Richard III and Othello, whose humanity, albeit "dysfunctional," remained relatively safeguarded and was never unequivocally negated. In her insightful analysis of Henry VI, Part II performed in the context of the St Albans miracle, Lindsey Row-Heyveld discusses the

3 "What have we here? A man or a fish? Dead or alive? [...] Were I in England now as once I was, and had but this fish painted, not a holiday fool there but would give a piece of silver. There would this monster make a man: any strange beast there makes a man: when they will not give a doit to relieve a lame beggar, they will lay out ten to see a dead Indian. (The Tempest, 2.2.24-31); as Plunkett demonstrates, raree show, or peepshow originated rather later, towards the second half of the seventeenth century (Plunkett, 2015: 7-30). 
presence and transformation of the medieval approaches to dis/ability in early modern England, whereby the "non-standard body served as a conduit for God" (Row-Heyveld, 2009), allowing the congregation to bestow acts of benevolence, such as alms upon the disabled in order to aid rich sinners in the task of salvation. Row-Heyveld addresses the charges of fraudulent dis/ability and false miracles in the high Middle Ages and towards the beginning of the early modern era, pointing to anxiety and fear as reactions to vagrancy, and the threat of disabled beggars who were believed to dissimulate their ailments, the belief perpetuated by much of the rogue literature of the time. Significantly for the presentation of Caliban as a lazy slave in The Tempest, the onset of Reformation put a stop to the spiritual and monetary exchange between the rich and the disabled, changing the predominant attitudes toward those unable to work: "with this shift came an increased emphasis on the necessity of separating the deserving poor from the undeserving poor. Disability was central to this distinction. The undeserving poor were categorised as those persons who were able but unwilling to work while the deserving poor were defined as those who were willing but unable to work" (Row-Heyveld, 2009). This cultural anxiety surrounding dis/abled bodies seems to have been additionally fuelled by the fear of effeminisation brought about by the presence of strong women vying for power and the fact that in the context of "highly unstable early modern masculinity, even jesting at the possibility of physical emasculation was enough to ensure social emasculation" (Row-Heyveld, 2009). To be recognised as one unable to perform labour meant especially for a male to have one's identity reduced; social recognition of ablebodiedness was therefore dependent upon acts of bodily reading and reception/ rejection as (non-)masculine.

In her reflection on the history of disability in the early modern England, Row-Heyveld makes an important caveat that dis/ability is a modern term and that to use it with reference to the texts of the past is to perform an act of anachronistic reading; such a practice points specifically to the project of dis/ ability studies as distinct from the study of monstrosity. It is, however, important not to bypass the connection established in various societies between dis/ability as something that is perceived as non-normalcy and monstrosity. A genealogy of dis/ability has already been sketched through the historicising reflection on the "abnormal" undertaken by Michel Foucault. In his 22 January 1975 Collège de France lecture, Foucault discussed three figures central for the understanding of the notion of abnormality that arose in the nineteenth century: the "human monster," the "individual to be corrected," as well as the "masturbating child" (Foucault, 2003: 55). The human monster, "the fundamental figure around which bodies of power and domains of knowledge are disturbed and reorganised" (Foucault, 2003: 63), is doubly transgressive, as it represents a deformation at the natural and societal level. The medieval bestial man, the early modern two-bodied individual (Siamese twins), and the classical age hermaph- 
rodite all constitute different forms of monstrosity that ultimately arises only where "the confusion comes up against, overturns, or disturbs civil, canon, or religious law" (Foucault, 2003: 63), contradicting the existing religious and legal classifications.

According to Foucault, the post-Enlightenment era saw a paradigm shift in the treatment of monstrosity, attributable to two major changes: one in the development of psychology and the other in the emergence of the corrective state that seeks to transform and normalise the deviant individual. Monstrosity thus slipped the unalterable natural order of things and moved into the regions of the abnormal. Foucault's views on abnormality were preceded by his insight into the nature of disease in The Birth of the Clinic (1963) and the views of his teacher, Georges Canguilhem, for whom "the normal type [was] the degree zero of the monstrosity" (Canguilhem, qtd in Lawlor and Nale, Kindle) and who, following in the footsteps of such theoreticians as Claude Bernard and Kurt Goldstein, transformed the thinking on the norm and the normative, especially in medical epistemology. ${ }^{4} \mathrm{He}$ reflected on its historical indebtedness to the idea of the natural that, together with the onset of industrialisation and the advance of social sciences, was replaced by the concept of normality. Canguilhem's thinking on the ontology of the norm in the sphere of medicine revealed a continuum between the normal and the pathological. On the strength of this logic, Foucault constructed his own argument that modern societies create an apparatus for a transformation of irregularity and extended it to discuss the emergence of modern medicine and its connection with disease as a function of life. In the sphere of medical science, the emphasis on the sense of a continuum between normality and abnormality translates into the emergence of the medical gaze that scrutinises the body for signs of failure to comply to the normative model of health and treats disease as functional deviance. This allows for a broad reading of illness, mental illness included, as a pervasive state, prevented only by a continuous regimen of care and control. The ab-normal becomes thus a function of the normative: "Disease loses its old status as an accident and takes on the internal, constant, mobile dimension of the relation between life and death [...] Deviation in life is of the order of life, but of a life that moves towards death" (Foucault, 1973: 191).

A reflection on the normal and the pathological and the paradigm shift in the understanding of the nature of health, disease and dis/ability as a continuum of life, has, as I would like to argue, some bearing on the way that the figure of Caliban has been constructed in modern theatre, both in Poland and abroad. The shift in the understanding of the individual subject and its constituent "abnormality" seems to add another interpretive layer to the ways in which the character

\footnotetext{
${ }^{4}$ See: Pasquinelli (2015: 79-89).

5 See: Canguilhem (1962: 27-43); Canguilhem (1991); Davidson (1991: 36-68); Sharpe (2010); Elden (2001: 91-105); Rai (2004: 538-570).
} 
of Caliban has been envisioned, staged, but also alluded to in diverse contexts. ${ }^{6}$ Here I would like to focus on dis/ability as a major defining feature shaping Caliban on the stage in selected Polish productions of The Tempest. A cursory glance at these stagings suggests that it is possible to envision interpretations of the play that bring to the fore the paradigmatic shift from monstrous to pathological as a social construct and underline Caliban's "deformity" in bodily terms even more than it is visible in the playtext or in the majority of productions read alongside the post-colonial key. Such an approach is substantiated in a number of twentieth and twenty-first century theatrical and film productions which move away from the presentation of Caliban as a human-animal hybrid or a plant-like racialised Other and accentuate his state of in/ability instead.

In Krystyna Skuszanka's 1989 Teatr Mały production in Warsaw, Caliban (Paweł Galia) is described in the programme as "a living sign of tormented humanity with its unknown future" (Skuszanka, 1989: cover) and presented as a non-distinct figure wrapped in bandages, which allows for a number of free associations with disease, be it syphilis, leprosy, or other affliction affecting the whole of the body, with the skin as the area that seems to be most affected by the condition. Caliban's "deformed" state seems to have been fashioned into the most decisive marker of his humanity; the continuity of the pathological spectrum, from disease/disability to health, can be traced in the way all the three characters of Miranda, Ferdinand, and Caliban - misfits in the empire of Prospero - are dressed, as only they wear white. A sense of continuum between the norm and the abnormal is visible also in the 2015 production of The Tempest by Krzysztof Garbaczewski, where Caliban (Paweł Smagała) is fashioned into a carnivalesque-grotesque with a hunchback, whose main desire is to be humped by Miranda (Małgorzata Gorol). The character copulates with a spine and fragments of a backbone that he claims are his mother's and seems to fit into all the three categories described by Foucault as the "human monster," the "individual to be corrected," as well as the "masturbating child." Still he remains the most virulent of all the island inhabitants, whose malaise is accentuated by the claustrophobic setting consisting of a reversed black island hanging over the characters' heads. Even the female ruler of the island, Prospera, is touched by the sense of the post-apocalyptic demise and suffering: coughing, with her bold head and pained movements, she rules over/under the island with the quiet desperation of a dying cancer patient. According to Paweł Soszyński, this postdramatic adaptation investigates the broken character of performatives, pointing to the crucial significance of Caliban as the figure through whom The Tempest reaches back to the nineteenth century comedy conventions, but also brings to

${ }^{6}$ Lennard J. Davis notes that where dis/abled characters appear in literature "the disabled character is never of importance to himself or herself. Rather, the character is placed in the narrative 'for' the nondisabled characters - to help them develop sympathy, empathy, or as a counterbalance to some issue in the life of the 'normal' character" (Davis, 2002: 45). 
the fore associations with the "not fully formed, aborted embryo-monster" who "deforms Shakespearean poetics" (Soszyński, 2016).? The dramatic theatre rules are playfully broken by Smagała's flickering in and out of his role in the video installation interludes: these create an overall sense of fluid identity. The state of generalised pathology in this production with Caliban as the focal point can, as Lennard Davis points out, indicate that "disability may prove to be the identity that binds everyone else together" (Davis, 2002: 26-27).

The 2016 staging of The Tempest by Anna Augustynowicz (Teatr Współczesny, Szczecin), pushes the disabled/diseased imagery further: in this theatrical production, all the characters are hospital patients, while the wheelchaired Caliban (Arkadiusz Buszko) is pushed around by his heavily pregnant mother, listed as Sycorax's Ghost (Ewa Sobiech). Despite his very pronounced in/ability to move, Buszko's Caliban remains one of the most active characters on the stage; his wheelchair does not seem to function as much of an obstacle in the virtuoso scheming he is preoccupied with throughout the performance. The reviewers paid heed to the dis/abled presentation of Caliban in Augustynowicz's production: where Ewa Podgajna describes this Caliban simply as "a disabled monster desiring freedom to primitively take the power over and avenge himself" (Podgajna, 2016), Joanna Ostrowska discovers far more nuance in the use of dis/ability in Caliban's portrayal and underlines his full participation in the cynical powerplay on the island as a major political player (Ostrowska, 2016). The in/ability, which rather significantly leaves Caliban untouched but which affects all the islanders and the castaways alike, is the gradual loss of language, whose artfulness is audible from the onset of the play when the characters are manipulated into speaking by Prospero. In the epilogue, it is Prospero that loses control over his body and his voice, and succumbs to echolalia: his body contorts, his voice spills out of control, and his final words become inarticulate. Thus, his master's voice is gone.

Just like Skuszanka's and Garbaczewski's productions, Augustynowicz's version offers a re-contextualisation that pushes Caliban into the realm of the pathological; this shift seems to be tied to a paradigmatic change which has occurred firstly in the modern approach to the Western understanding of the nature of diseased states, as discussed by Georges Canguilhem in his The Normal and the Pathological and secondly in a changing response to The Tempest as a play whose utopian hope is dimmed by the modern preoccupation with (post)humanity and the problematic definitions of life and death, disease and health, in/ability and ability. ${ }^{8}$ Even though dis/ability of Caliban is performed by able-bodied actors, the context of the performance allows a subversive reading of thus marked body.

\footnotetext{
${ }^{7}$ If not otherwise indicated, all translations are mine, A. K-P.

${ }^{8}$ I have written more about the reception history of the play in: Kowalcze-Pawlik (2021: 121-138).
} 
As Toby Siebers writes, such representations of disability are a part of a "symbolic process [that] removes individuals from the ranks of quality human beings, putting them at risk of unequal treatment, bodily harm, and death" (Siebers, 2010: 23). Skuszanka, Garbaczewski, and Augustynowicz lay the process bare, showing its artificiality. This, however, is not without its own risks: dis/ability is thrown at our faces as a universal human condition to warn us against our own monster within. At the same time, however, the diagnosis of sick art/sick culture is built on the strength of a representation of dis/ability that by using dis/ability as a mode of representation seems to bypass individuals with dis/ability, thus disqualifying them as individuals exactly because able bodied actors simulate dis/ability as inability pushing dis/ability back towards the discourse of the pathological.

Are other scenarios, other ways of representing dis/ability possible? The answer to this question is provided by the amateur production Rozbitkowie [Castaways], directed by Justyna Lagowska and based on The Tempest, staged at the Teatr Ludowy in Krakow in March 2020. This is not a show to be watched; rather, it is a predominantly haptic and aural performance, which seems to heal the excess of visual stimuli that the theatre offers on a daily basis to its spectators. Maciej Namysło plays the role of Ariel, who organises the stage space as an air-borne intermediary between the actors and the audience, leading the nonseeing cast to their seats around the big round table in the middle of the stage and walking along the rows of chairs set against the walls to initiate dialogue with the audience members, encouraging them to touch the props. Namysło discusses the project as follows:

We have created a value that is neither a radio play nor a theatre performance. It's something in between. You can participate in the performance as a seeing person and in the same way perceive the performance while being blind or partially sighted. (Namysło qtd in Kalęba, 2020)

Castaways was the culmination of the two-year "Guides of the senses" workshops for the visually impaired: the overall aim was to "create a new form of a theatrical event, rejecting the sense of sight and provoking viewers to perceive the performance with their other senses" (Namysło, 2020). The set design, props and the sound were focused on performance reception through hearing, touch, and smell. Reliance on such senses demanded a largely immersive theatrical experience, whereby the surroundings acquired a new and changed meaning. Hence, the insistence on the continued process of taming the space, rendering it friendly and safe to all the participants in the performative event: the audience, dis/abled and able-bodied cast alike. The tempest in this project is not yet there and the island in itself is presented as a pre-lapsarian space, untouched by the presence of the castaways, as the ship bringing forth change is only looming on the horizon. The project participants speak through their chosen non-human alter egos, taking 
the form of small animals and, most of the time, concentrate on discussing what the island means to them. Through these impromtu exchanges the oikoumene of the non-human characters is therefore established not as a place of exile but as their home. Prospero, who initially does not seem to share the sentiment and who controls the visually impaired Miranda out of concern for her, gradually seems to come to a realisation that his constant care does not render her happy, nor does it lead to her independence or freedom. In this performance, it is hard to miss out on the central importance of Ariel, who not only discreetly takes care of the needs of the island's residents, but also teaches the audience that you do not have to use your sight to understand the performance or to participate in it.

Out of Shakespeare's original characters populating the island at the beginning of the play, Caliban is the one who seems to be missing most conspicuously. This absence from the stage, however, seems only provisional. The audience, shyly exploring the space in which the remaining "castaways" feel at home, is at odds at first and very clumsily tries to accommodate to a changed environment peopled by vulnerable, fragile, beautiful bodies that welcome the audience as guests. The attempt to find a language to describe this new reality is their predicament. In this scenario, it is the audience that seems to assume the role of Caliban and is faced with the possibility of making the island their home, while trying to find a new language to describe the different theatrical experience.

The discussion of the representations of dis/ability in selected Polish theatrical adaptations of The Tempest would not be complete without asking about the reception of dis/ability on the stage. Just like any other analysis of the portrayals of disability in culture, the reflection on the significance of Caliban in the three theatrical performances discussed above is shaped by a reading making use of the disability studies methodology. Even though theatrical criticism in the form of theatrical reviews can be sourced for examples of expert approach usually devoid of the disability reception component, it would be even more useful to know what regular theatre-going public makes of dis/ability on the stage, as the recognition of the cultural presence of disabled figures is only partial without the knowledge of the audiences' reactions and the result of interventionist projects, such as Castaways.

Castaways is a potent contributor in shaping an approach to dis/ability which is devoid of the "teratological impulse" ushered by the very use of disability in the productions, where able-bodied actors produce it to obtain a specific effect. Even if in the process disability is critically interrogated as a social and political construct, the fact of non-visibility of dis/abled actors remains a given in the Polish theatrical world. Thus, even such critically minded productions as the adaptations of The Tempest by Garbaczewski and Augustynowicz do not provide a break from the normative model. Both of them cast ability as the "norm," and create dis/ability as in/ability, i.e. a failure disappointing the predominant cultural expectations that concern the "productive, useful, unified citizen's body" (Hadley, 2014: 6). 
As Bree Hadley argues in her major contribution to the understanding of the presence of dis/ability on the stage, Disability, Public Space, Performance and Spectatorship, when dis/ability is created as "all that is Other," the audiences do not truly "encounter" the disabled, while still relying on the pre-existing "violence of recognition, categorisation and comprehension" (Hadley, 2014: 7). What seems to be missing in the two productions, but what emerges as a focal point in Castaways, is what Hadley calls "ethical encounters." Spectators watching the performance might develop various understandings of the position dis/ability occupies on the stage, but the very fact of bringing dis/ability to the fore in the public sphere of theatre might open them to a re-evaluation of their own approach towards disability (Hadley, 2014: 26). The invitation to participate in the production not through the visual medium but through other senses and the consistent use of the tactile and the aural in the performance allow for a change in perspective, which stems from a major difference in participation in the theatrical experience, creating a sense of bodily difference in the audience, thus possibly also affecting the understanding of disabled and non-disabled bodies, "the social relationships, scripts and rules that inform these reactions, casting the disabled body as sources of curiosity, discomfort, stigma or pity" (Hadley, 2014: 2). This performance effect was further strengthened by the post-performance reception, during which the audience members were introduced into the project and the production cast and theatre staff had the opportunity to engage into a very informal Q\&A, where the project team very subtly steered the event to include everyone and to facilitate discussion. The audience's post-performance reaction suggests a very favourable reception, but from the room dynamics it was clearly visible that the majority of spectators were somehow connected to the cast members, family, friends of theatre supporters. Dis/ability in this particular instance seems to have been fashioned into a "positive symbol of difference" (Hadley, 2014: 31), which asks important questions about the significance of theatrical space as a site that can be intervened into to accommodate the presence of bodies with dis/abilities without the risk of exposing them to a non-dis/abled gaze assuming its regular hegemonic position.

\section{Bibliography}

Burnett, Mark Thornton, 2002: Constructing "Monsters" in Shakespeare's Drama and Early Modern Culture. Basingstoke: Palgrave Macmillan.

Bolt, David, 2012: "Social Encounters, Cultural Representation, and Critical Avoidance." In: Routledge Handbook of Disability Studies. Eds. Nick Watson, Alan Roulstone and Carol Thomas. London: Routledge, 287-297.

Canguilhem, Georges, 1962: "Monstrosity and the Monstrous.” Diogenes, no. 40 (winter), 27-43.

Canguilhem, Georges, 1991: The Normal and the Pathological. New York: Zone Books. 
Covey, Herbert, 2000: "Shakespeare on Old Age and Disability." The International Journal of Aging and Human Development, no. 50.3, 169-183.

Davidson, Arnold, 1991: "The Horror of Monsters.” In: The Boundaries of Humanity. Eds. James Sheehan and Morton Sosna. Berkeley: University of California Press, 36-68.

Davis, Lennard J., 2002: Bending Over Backwards: Disability, Dismodernism and Other Difficult Positions. New York: New York University Press.

Elden, Stuart, 2001: "The Constitution of the Normal: Monsters and Masturbation at the Collège de France." Boundary, no. 2.28(1), 91-105.

Foucault, Michel, 2003: Abnormal: Lectures at the Collège de France, 1974-1975. New York: Picador.

Foucault, Michel, 1963: The Birth of the Clinic. New York and London: Routledge.

Franssen, Paul, 1997: “A Muddy Mirror.” In Constellation Caliban: Figurations of a Character. Eds. Nadia Lie and Theo D'Haen. Amsterdam: Rodopi, 23-42.

Griffiths, Trevor R., 1983: “"This Island's Mine:' Caliban and Colonialism.” Yearbook of English Studies, no. 13, 159-180.

Hadley, Bree, 2014: Disability, Public Space Performance and Spectatorship: Unconscious Performers. Basingstoke: Palgrave Macmillan.

Hall, Kim, 1995: Things of Darkness: Economies of Race and Gender in Early Modern England. Ithaca: Cornell University Press.

Hankins, John E., 1947: "Caliban the Bestial Man." Publications of the Modern Language Association of America, no. 62/3, 793-801.

Jaczminski, Daniel, 2009: "Liberating the Strange Fish: Visual Representations of Caliban and Their Successive Emancipation from Shakespeare's Original Text." In: Word and Image in Colonial and Postcolonial Literatures and Cultures. Ed. Michael Meyer. Amsterdam: Brill/Rodopi, $1-19$.

Kalęba, Julia. "Nowy spektakl Teatru Ludowego Rozbitkowie współtworzyły osoby niewidome." https://gazetakrakowska.pl/nowy-spektakl-teatru-ludowego-rozbitkowie-wspoltworzylyosoby-niewidome/ar/c13-14840806, 7 March 2020. Accessed: 25 Sept 2020.

Kowalcze-Pawlik, Anna, 2011: "What's Past is Prologue: the Age of Caliban." Studia Litteraria Universitatis Iagellonicae Cracoviensis, no. 6, 53-63.

Kowalcze-Pawlik, Anna, 2021: "Meaningless Acts: Migratory Aesthetics in Krzysztof Warlikowski's and Paweł Miśkiewicz's Dystopian Adaptations of The Tempest." Teatralia, no. 24, 121-138.

Lawlor, Leonard, and John Nale, (eds.) 2014: “Monster." The Cambridge Foucault Lexicon, Cambridge: Cambridge University Press, Kindle Edition, 300-303.

Longmore, Paul K., 2003: Why I Burned My Book and Other Essays on Disability. Philadelphia: Temple University Press.

McCloskey, J. C., 1940: “Caliban, Savage Clown.” College English, no. 1(4), 354-357.

Mitchell, David T., and Sharon L. Snyder, 2000: Narrative Prosthesis: Disability and the Dependencies of Discourse. Ann Arbor: University of Michigan Press.

Nixon, R., 1987: "Caribbean and African Appropriations of The Tempest." Critical Inquiry, no. $13 / 3,557-578$.

Ostrowska, Joanna, 2016: "Panowanie nad Burzą." https://teatralny.pl/recenzje/panowanie-nadburza,1504.html, 8 April 2016. Accessed 25 Sept 2019.

Pasquinelli, Matteo, 2015: "What an Apparatus Is Not: On the Archeology of the Norm in Foucault, Canguilhem, and Goldstein." Parrhesia, no. 22, 79-89.

Plunkett, John, 2015: "Peepshows for All: Performing Words and the Travelling Showman." Zeitschrift für Anglistik und Amerikanistik, no. 63.1, 7-30.

Rai, Amit S., 2004: "Of Monsters - Biopower, Terrorism, and Excess in Genealogies of Monstrosity." Cultural Studies, no. 18.4, 538-570. 
Row-Heyveld, Lindsey, 2009: “'The lying'st knave in Christendom': The Development of Disability in the False Miracle of St. Alban's." Disability Studies Quarterly, no. 29.4. www. dsq-sds.org/article/view/994. Accessed 8 Jan 2021.

Rozbitkowie [Castaways]. Dir. Justyna Łagowska. Teatr Ludowy, Kraków-Nowa Huta, 7 March 2020.

Podgajna, Ewa, 2016: "Burza zagrana dziś i na jubileusz Teatru Współczesnego" [The Tempest Played Today and for the Współczesny Theatre Jubilee]. Gazeta Wyborcza - Szczecin 67, 20 March 2016. https://szczecin.wyborcza.pl/szczecin/7,34939,19795877,burza-zagrana-dzisiaji-na-jubileusz-teatru-wspolczesnego.html\#ixzz43WPb2IOZ. Accessed 28 Sept 2019.

Rundle, Erika, 2007: "Caliban's Legacy: Primate Dramas and the Performance of Species." TDR: The Drama Review: A Journal of Performance Studies, no. 51/1, 49-62.

Sharp, Corona, 1981: "Caliban: The Primitive Man's Evolution.” Shakespeare Studies, no. 14, 267-83.

Sharpe, Andrew, 2010: Foucault's Monsters and the Challenge of Law. Routledge: New York.

Shakespeare, William, 2016: The Tempest. The Norton Shakespeare. 3rd edition. Eds. Stephen Greenblatt et al. New York and London: W.W. Norton.

Shakespeare, William, Burza [The Tempest]. Dir. Krystyna Skuszanka. Teatr Narodowy, Warsaw, 2 March 1989.

Shakespeare, William, Burza [The Tempest]. Dir. Krzysztof Garbaczewski. Teatr Polski, Wrocław, 7 February 2015.

Shakespeare, William, Burza [The Tempest]. Dir. Anna Augustynowicz. Teatr Współczesny, Szczecin, 19 March 2016.

Siebers, Tony, 2010: Disability Aesthetics. Ann Arbor: University of Michigan Press.

Soszyński, Paweł, 2015: "W krzywym lustrze Prospery" [In Prospera's Distorted Mirror]. Dwutygodnik. www.dwutygodnik.com/artykul/5724-w-krzywym-lustrze-prospery.html, $10 \mathrm{Feb}$ 2015. Accessed 24 Sept 2019.

Vaughan, Alden T. and Virginia Mason-Vaughan, 1993: Shakespeare's Caliban: A Cultural History. Cambridge: Cambridge University Press.

Wilson, Daniel, 1873: “Caliban the Monster.” In: Caliban: The Missing Link. London: Macmillan and Co.

Wilson, Jeffrey R., 2018: “'Savage and Deformed': Stigma as Drama in The Tempest." Medieval and Renaissance Drama in England: An Annual Gathering of Research, Criticism and Reviews, no. 31, 146-177.

\section{Bio-bibliographical Note}

Anna Kowalcze-Pawlik, Ph.D is an Assistant Professor at the Department of the British and Commonwealth Studies at the Faculty of International and Political Studies, University of Lodz, where she teaches literary and cultural studies and serves as the academic secretary of International Studies: Interdisciplinary Political and Cultural Journal. Her main fields of research are literary studies and translation: revenge in literature, early modern women writers, Shakespeare in performance, and Shakespeare in translation. She is currently working on the history of the Polish reception of Shakespeare's The Tempest.

(anna.kowalcze@uni.lodz.pl) 